Treatment of Chronic Brucellosis with Trimethoprim-sulphamethoxazole

\begin{tabular}{|c|c|c|c|c|c|c|c|}
\hline $\begin{array}{l}\text { Case } \\
\text { Ṇo. }\end{array}$ & Sex & $\begin{array}{c}\text { Age } \\
\text { (Years) }\end{array}$ & $\begin{array}{l}\text { Blood and Bone } \\
\text { Marrow Cultures }\end{array}$ & $\underset{\text { Titre }}{\text { Serum Agglutination }}$ & $\begin{array}{l}\text { No. of Days to Become } \\
\text { Afebrile }\end{array}$ & Relapses & $\begin{array}{l}\text { Serum Agglutination } \\
\text { Titre After } 2 \text { Years }\end{array}$ \\
\hline $\begin{array}{r}1 \\
2 \\
3 \\
4 \\
5 \\
6 \\
7 \\
8 \\
9 \\
10 \\
11 \\
12 \\
13 \\
14 \\
15 \\
16 \\
17 \\
18 \\
19 \\
20\end{array}$ & $\begin{array}{l}\text { F. } \\
\text { F. } \\
\text { M. } \\
\text { M. } \\
\text { M. } \\
\text { M. } \\
\text { M. } \\
\text { M. } \\
\text { F. } \\
\text { M. } \\
\text { F. } \\
\text { M. } \\
\text { M. } \\
\text { M. } \\
\text { M. } \\
\text { M. } \\
\text { F. } \\
\text { M. } \\
\text { M. }\end{array}$ & $\begin{array}{l}60 \\
48 \\
53 \\
20 \\
53 \\
67 \\
46 \\
31 \\
30 \\
55 \\
23 \\
50 \\
58 \\
17 \\
60 \\
45 \\
26 \\
45 \\
59 \\
45\end{array}$ & 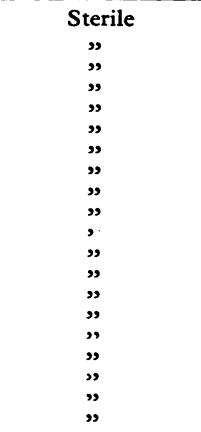 & $\begin{array}{l:r}1 & : 1280 \\
1 & 640 \\
1 & 1280 \\
1 & : 1280 \\
1 & 640 \\
1 & 1280 \\
1 & 1280 \\
1 & 1280 \\
1 & 640 \\
1 & 1280 \\
1 & 1280 \\
1 & : 1280 \\
1 & : 1280 \\
1 & 640 \\
1 & 1280 \\
1 & 1280 \\
1 & 1280 \\
1 & 1280 \\
1 & 640 \\
1 & : 1280\end{array}$ & $\begin{array}{l}3 \\
4 \\
4 \\
2 \frac{1}{2} \\
4 \\
2 \\
5 \\
4 \\
3 \\
3 \\
3 \\
4 \\
3 \\
3 \\
7 \\
4 \\
4 \\
3 \frac{1}{2} \\
2 \\
3 \frac{1}{2}\end{array}$ & $\begin{array}{l}\text { No } \\
\text { No } \\
\text { No } \\
\text { No } \\
\text { No } \\
\text { No } \\
\text { No } \\
\text { No } \\
\text { No } \\
\text { No } \\
\text { Yes } \\
\text { No } \\
\text { No } \\
\text { No } \\
\text { No } \\
\text { No } \\
\text { Yes } \\
\text { No } \\
\text { No } \\
\text { No }\end{array}$ & $\begin{array}{c}1: 160 \\
\text { Neg. } \\
1: 80 \\
1: 160 \\
\text { Neg. } \\
1: 160 \\
1: 160 \\
\text { Neg. } \\
\text { Neg. } \\
1: 80 \\
1: 80 \\
1: 80 \\
1: 80 \\
1: 80 \\
\text { Neg. } \\
1: 80 \\
1: \text { Neg. } \\
1: 160\end{array}$ \\
\hline
\end{tabular}

either inadequate treatment or reinfection. The rest had no trouble during the two-year follow-up and were apparently cured. We believe, despite the two failures, that co-trimoxazole can be used effectively in the treatment of chronic brucellosis and that our dosage schedule is adequate, though more information is needed about the long-term results.

1 Hassan, A., et al., British Medical fournal, 1971, 3, 159.

2 Lal, S., et al., British Medical fournal, 1970, 3, 256.

3 Giunchi, G., De Rosa, F., and Fabiani, F., Chemotherapy, 1971, 16, 332.

4 Daikos, G. K., et al., fournal of Infectious Diseases, 1973, 128 Supp., 731.

5 British Medical fournal, 1974, 1, 299.

State Hospital for Infectious Diseases, Athens, Greece

P. A. KONTOYANNIS, M.D., Head Medical Department

S. E. PAPAPOULOS, M.D., Senior House Officer

A. A. MORTOGLOU, M.D., Senior House Officer in Medicine

\section{Orbital Bruits in Patients on Maintenance Haemodialysis}

Cranial or onbital bruits, or both, are typically heard in patients with cranial arteriovenous fistula and angioma. In children cranial bruits may be heard as a result of transmission of cardiac murmur to the cranium. Other conditions with cranial bruits include carotid artery stenosis and intrathoracic aneurysm, aneurysm of the posterior fossa, Paget's disease of the skull, aortic stenosis, and arterial hypertension in young children. Cranial bruit was first noted in an anaemic woman 44 years $\mathrm{ago}^{1}$ and several cases were described recently. ${ }^{2}$ As most patients with renal failure on maintenance dialysis have severe anaemia, it was reasoned that these patients may also have cranial bruit and a study was made.

\section{Case History}

Twenty-two patients on maintenance haemodialysis were studied at the University of Illinois Hospital. The diaphragm of the stethoscope was placed lightly on the orbit with the patient's eyes closed. Auscultation was done while the patient held his breath, before, during, and after dialysis and after occlusion of arteriovenous fistula. The bruits were graded as follows: grade $0=$ bruit absent, grade $1=$ bruit just audible, grade $2=$ bruit easily audible, and grade $3=$ loud bruit. The blood pressure, pulse rate, presence of cardiac murmurs, carotid bruits, haematocrit value, and weight before and after dialysis were recorded. Statistical analysis was computed by the paired $t$ test. Orbital bruits were absent in five patients, grade 1 in five, grade 2 in seven, and grade 3 in five. After occlusion of the arteriovenous fistula the bruit was absent in eight patients, grade 1 in six, grade 2 in six, and grade 3 in two. There was no change in the intensity of the bruit before, during, or after dialysis. The mean haematocrit value was $20 \%$ (range 12.4-30.5\%). The patients with orbital bruits had a lower haematocrit value than those without $(P<0.2)$, but there was no direct correlation between its level and the intensity of the bruit. The average blood pressure was $135 / 85 \mathrm{~mm}$. (range 70/50-160/10). The mean pulse rate was 89/min (range 76-120). The (range $70 / 50-160 / 110)$. The mean pulse rate was $89 / \mathrm{min}$ (range $76-120$ ). The heard in 16 patients and carotid bruits in six. None of these factors had any effect on the presence or intensity of the bruits.

\section{Discussion}

Examination of the head for cranial and orbital bruit is not routinely done though the many conditions that may produce them highlight the importance of this examination, particularly in pat:ents with neurological and cardiac abnormalities. Severe anaemia increases cardiac output, which leads to an inoreased cerebral blood flow. ${ }^{4}$ There is also generalized vasodilatation and decrease in blood viscosity. Under these circumstances cranial bruits are thought to result from turbulent blood flow in the cerebral arteries. Patients on maintenance haemodialysis have severe anaemia and, not surprisingly, orbital bruits are usual in these patients. The bruit appears to be intensified by an anteriovenous fistula; this is supported by the disappearance of some bruits and reduction in intensity of others with occlusion of the fistula. The fistula may contribute to $12 \%$ increase in cardiac output ${ }^{5}$ and this may be higher with large fistula. Some patients develop heart failure because of the high output state. Patients on maintenance haemodialysis may develop various neurological abnormalities such as convulsions, stroke, and subdural haematoma. Nevertheless, the presence of a cranial bruit should not be readily attributed to an intracranial lesion. Recognition of anaemia as the cause of the bruit should make extensive examination unnecessary unless other neurological disorders are present.

${ }^{1}$ Hamburger, L. P., American fournal of the Medical Sciences, 1931, 181 756.

Gareebo, H., British Medical fournal, 1968, 1, 294.

3 Gardner-Thorpe, C., British Medical fournal, 1968, 1, 445.

${ }^{4}$ Heyman, A., Patterson, J. L., and Duke, T. W., Fournal of Clinical Investigation, 1952, 31, 824

${ }^{5}$ Charra, B., et al., Kidney International, 1973, 3, 51.

V.A. West Side Hospital and University of Illinois; Abraham Lincoln School of Medicine, Chicago, Illinois

S. R. LANCER, B.S., Final year medical student

L. F. GUTIERREZ, M.D., Physician

V. K. G. PILLAY, M.R.C.P., Chief, Section of Nephrology 